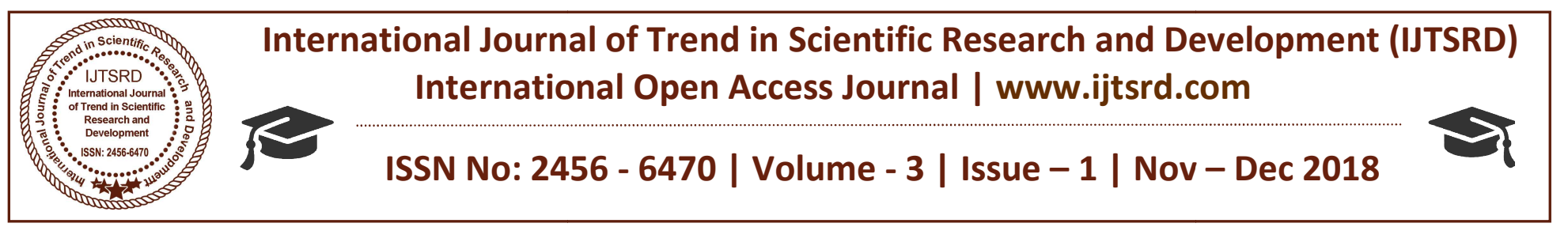

\title{
The Effect of External Economic Factors on Return on Average Equity on the Selected Rwandan Commercial Banks: Using Panel Data Regression Model
}

\author{
Habimana Theogene ${ }^{1}$, Habinshuti Patrice ${ }^{2}$, Mudaheranwa Benjamin ${ }^{3}$, Mutambuka Deo ${ }^{4}$ \\ ${ }^{1,2,3}$ Regent University’s Business Development Center, BDC Rwanda \\ ${ }^{3}$ Christian University of Rwanda, Kigali, Rwanda, East Africa
}

\section{ABSTRACT}

The general objective of this paper was to examine the effect of external economic factors on Return on average Equity (R) in the selected Rwandan commercial banks. We used secondary data as practical means of obtaining information related to the research topic. The data were obtained from 12 commercial banks in Rwanda. In collecting secondary data, annual reports were used. Financial reports of 2001-2017 of each commercial bank were used with the total observations number $(\mathrm{N})$ of $/ 2 * 17=$ 204.Panel data regression model, $Y=X \beta+\mu$ was applied in this study, where LM test (plmtest), Restricted F-test (pFtest) and Hausman test (phtest) were used. $\mathrm{R}$ programming language was also used as statistical tool. The findings indicated that there is a significant positive effect of inflation rate on return on average equity, there is no significant effect of GDP Growth rate on return on average equity, there is no significant effect of currency depreciation on return on average equity, there is a significant negative effect of private sector credit growth on return on average equity in Rwandan selected commercial banks. From the value of R-Squared equals to 0.22883 $=22.883 \%$, this study concluded that, inflation rate and private sector credit growth can only affect the return on average equity in commercial bank on the rate of $22.883 \%$ and the significant model is $\mathrm{R}=$ $25.80424+0.563706 \mathrm{I}-0.15664 \mathrm{P}$. This implies that there may be other factors, like internal factors that should affect the return on average equity in commercial banks.

Key Words: Economic Factors, Equity and Commercial Banks

\section{INTRODUCTION}

In early $1900 \mathrm{~s}$, the rubber plantations and tin industry were grown rapidly all-over the world, this created the need of banks and led to establishment of banking system, but the profitability of commercial banks worldwide was affected by the management of economic factors (Fisseha 2015). The main role of a financial system all-over the world is to lubricate the gears facilitating the economic operations. The banking system plays a major role in transferring funds from the saving units to the investing units. If a financial system is efficient, it should show improvements in profitability, increasing the volume of funds flowing from saver to borrowers, and better quality services for consumers (Levine \& Loayza, 2000). nt According to Pooran (2014) the major economic factors that affected commercial banks profitability in both developed and developing countries were regarded as the variability in net interest income and market value of equity due to changes in interest rates.

According to Ongore (2013) commercial banks in East Africa Community play a vital role in the economic resource allocation of countries. They channel funds from depositors to investors continuously. They can do so, if they generate necessary income to cover their operational cost they incur in the due course. In other words for sustainable intermediation function, banks need to be profitable. Beyond the intermediation function, the profitability of banks has critical implications for economic growth of countries. Good financial performance rewards the shareholders for their investment due to the economic factors. Commercial banks' profitability in East Africa over the last decade has not been impressive. Several reforms have been implemented in the 
commercial banks since 1990s aiming at increasing performance, stability, productivity, financial access and efficiency (Onuonga, 2014).

Rwanda's banking system is highly concentrated, but increasingly competitive as foreign banks increasingly look to enter the country. Around 50 percent of all bank assets in Rwanda are held by four to five of the largest commercial banks, while just one bank majority state-owned Bank of Kigali (BoK) - holds 30 percent of all assets. Currently, the banking sector is stable and well capitalized with an industry capital adequacy ratio of 22.5 per cent above 15 per cent central bank regulatory requirement. Rwanda's banking industry is composed of: commercial banks, development banks, cooperative banks, and microfinance banks. Local banks operate in both local currency and dollar-based accounts. While most suppliers are paid through wire transfers to their domicile bank accounts. Starting in 2008, the Rwandan Central bank fixed a capital requirement of five billion Rwanda Francs ( $\$ 6.5$ million) for commercial banks. All commercial banks have international correspondent banks operating in major cities of the world. Automatic Teller Machines (ATM) are available, but limited with only 400 in all of Rwanda. Commercial banks are authorized to provide loans in foreign currency (Bank of Kigali, 20178).

The government has implemented a financial sector development plan that improves access to financial services and competition in the banking sector and in micro-finance. The IMF gives the National Bank of Rwanda, Rwanda's central bank, high marks for its effective monetary policy. The overarching vision of the Government of Rwanda is to develop a stable and sound financial sector that is sufficiently deep and broad, capable of efficiently mobilizing and allocating resources to address the development needs of the economy and reduce poverty (Ministry of Finance and Economic Planning [MINECOFIN], 2018).

\section{PROBLEM STATEMENT}

The study of Manuel (2014) indicated that bank failure is a problem in many countries, he found that worldwide the years, 2007-2013, marked a new wave of bank failure, this period was characterized by high unpredictability and serious consequences due to lack of the effective of analysis of economic factors. While the study of Onuonga (2014) revealed that bank size, capital strength, ownership, operations expenses, diversification do significantly influence profitability of commercial banks. The study of Ayanda et al. (2013) also indicated that only broad money supply growth rate was found to be a significant driver both in the long run and in short run. Conflictingly, Kiganda (2014) found that macroeconomic factors (real GDP, inflation and exchange rate) do not affect bank profitability, implying that internal factors which relate to bank management significantly determine bank profitability. Moreover, from the above disagreements with different scholars, the researcher became in unbalanced academic position neither concluded that economic factors affect profitability of commercial banks or not. The above problem also supported by National Bank of Rwanda [BNR] annual report (2014), where Lerner index (average) was 0.48 in $2012,0.42$ in 2013, 0.45 in 2014, 0.38 in 2015, 0.32 in 2016 and 0.29 in 2017. In relation to Lerner index theory, the result clearly indicates a good progress in banking sector competition Rwanda since 2008, unfortunately the level of profitability of commercial banks in Rwanda were significantly different. Hence, in Rwanda commercial banks sector, considerable research effort has been devoted to and much debate has been evoked about the cause of bank failure. These have generated considerable insight into and understanding of the bank failure problem. However, the problem still remains large and keeps recurring, suggesting the need for more examination of the problem.

\section{OBJECTIVES OF THE STUDY}

The general objective of this paper was to examine the effect of external economic factors on Return On Average Equity (R) in the selected Rwandan commercial banks.

\section{RESEARCH HYPOTHESIS}

a) $\mathrm{H}_{0}$ : There is no significant effect of Inflation rate (I) on Return On Average Equity in Rwandan selected commercial banks.

$\mathrm{H}_{1}$ : There is significant effect of Inflation rate (I) on Return On Average Equity in Rwandan selected commercial banks.

b) $\mathrm{H}_{0}$ : There is no significant effect of GDP Growth rate $(G)$ on Return On Average Equity in Rwandan selected commercial banks.

$\mathrm{H}_{1}$ : There is significant effect of GDP Growth rate (G) on Return On Average Equity in Rwandan selected commercial banks. 
c) $\mathrm{H}_{0}$ : There is no significant effect of Currency Depreciation (C) on Return On Average Equity in Rwandan selected commercial banks.

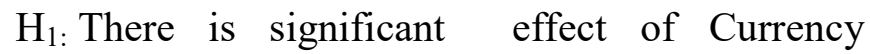
Depreciation (C) on Return On Average Equity in Rwandan selected commercial banks.

d) $\mathrm{H}_{0}$ : There is no significant effect of Private Sector Credit Growth (P) on Return On Average Equity in Rwandan selected commercial banks.

$\mathrm{H}_{1:}$ There is significant effect of Private Sector Credit Growth (P) on Return On Average Equity in Rwandan selected commercial banks.

Where, $\mathrm{H}_{0}$ means null hypothesis and $\mathrm{H}_{1}$ means alternative hypothesis

\section{CONCEPTUAL FRAMEWORK}

A conceptual framework is a research tool intended to assist a researcher to develop awareness and understanding of the situation under scrutiny and to communicate this. When clearly articulated, a conceptual framework has potential usefulness as a tool to assist the research to make meaning of subsequent findings (Yount, 2006). It forms part of the agenda for negotiation to be scrutinized and tested, reviewed and reformed as a result of research.

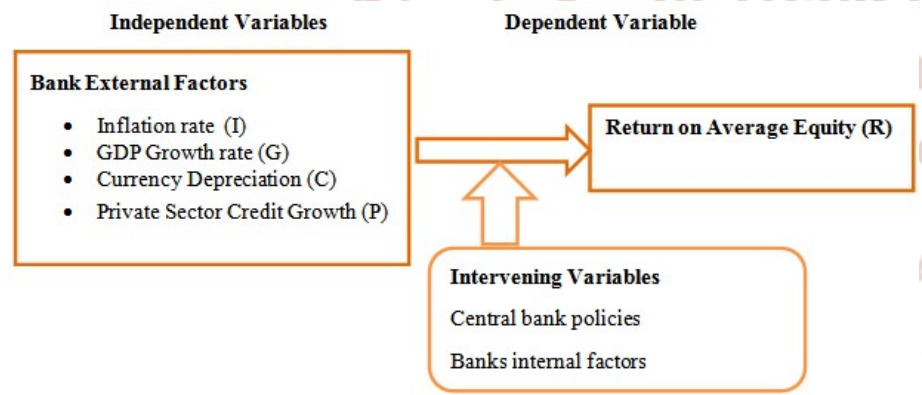

Figure 1: variables Presentations Source: Researcher, 2018

\section{SIGNIFICANCE AND SCOPE OF THE STUDY}

The study indicated the capacity of banks Rwanda to make high profits, by managing external economic factors. It should help to identify how the stakeholders maintain the competitiveness of their banks. It should help academicians with relevant information on the activities of the commercial banks in Rwanda and the analysis of economic factors. The investors could have information on which banks perform well and have wide choice in which banks to invest in relation the management of external economic factors. Due to limited or little time and resources, the study focused on the 12 best performer commercial banks in Rwanda. The study was for the period of 2001-2017, as in this period, most foreign commercial banks were interested to invest their money in Rwanda.

\section{RELATED STUDIES}

Waqas, Muhammad, Haseeb, Inam and Imran (2014) analyzed determinants of commercial banks profitability in Pakistan. The objective of the study was to examine the influence of commercial banks determinants on the performance of Pakistani banks over the time period from 2004-2010. The study used secondary data. Result indicated that the capital strength of a bank is utmost significance in affecting its performance, as a well-capitalized bank is observed to be less risky and such edge lead to high profitability. The assets quality, measured by the loans loss provisions, affects the performance of the banks positively and bank size as deposit indicates direct association with profitability as large banks earn more profit instead of small banks. The study also found that inflation affects the bank's profitability inversely as increase inflation affects banks cost that increased and its earning main source is its fee that it charge on its services but free services without any charges decrease in gross income that lead a reduction in profit.

Pooran (2014) carried out a study on factors affecting United Stated of America (USA). banking performance. The objective of the study was to determine the effects of bank specific factors and factors outside of the bank's control on bank profitability in the United States during the 2007-2013 financial crisis. The results, estimated by using generalized least square, showed that the bank market related factors, loan marketing strategies and portfolio diversification, explained most of the variability in bank profitability compared with bank specific factors, interest rate risk, credit risk, liquidity risk and capitalization risks, which explained about twenty three percent and macroeconomic/vocational factors, per capita income, bank size and bank locations, which explained about eleven percent of the variability in bank profitability. Among variables studied, loan marketing strategies and portfolio diversification, and interest rate risk and capitalization management strategies had a positive effect, while credit risk had a negative effect on profitability.

Ong and Teh (2013) analyzed factors affecting the profitability of Malaysian commercial banks. The objective of the study was to investigate the impact of bank-specific characteristics and macroeconomic 
conditions on Malaysian commercial banks financial performance, during the period of 2003 to 2009 . This study employs regression models that relate bank profitability ratios to various explanatory variables. There are three ratios which represent profitability measures are return on assets (ROA), return on equity (ROE) and net non-interest margin (NIM). Seven variables were drawn from the conventional banking literature as proxies for bank-specific and macroeconomic factors. Results of this study indicated that ROA is the best profitability measures.

Christos and Geoffrey (2014) analyzed the determinants of european bank profitability in European commercial banks. The objectve of the study was to review the literature on bank performance studies and classifies the bank profitability determinants. They constructed Ordinal Least Squares (OLS) and fixed effects models, and the results provided a new perspective for understanding the impact of changes in competition on the performance of the European banking industry. The estimation results suggest that the profitability of European banks is influenced not only by factors related to their management decisions but also to changes in the external macroeconomic environment.

Fisseha (2015) study focused meta analysis on the determinants of commercial bank's profitabilityin India. The purpose of the study was to review the determinants of commercial banks' profitability and to compare or combine results across sets of similar studies and contrasting the significant deviations in those findings by different scholars and to suggest a comprehensive model that incorporates macroeconomic, industry-specific and bank-specific determinants of commercial banks profitability. To achieve these objectives the study has been designed to gleaned data from various national and international journal articles together with the basic theories relating to the determinants of commercial bank's profitability irrespective of countries or economic level in which the banks are operating. While the results on bank specific and macroeconomic factors are explicit and point to one directional effect to bank performance, the results on the impact of industry specific factors are mix and in most cases insignificant to explain the behaviour of banks.

Brunilda and Elvana (2015) analyzed factors influencing the bank profitability in Albania. The primary objective was to investigate the determinants of the profitability and to present all the debates through the literature review on the profitability. On the other hand internal factors of the banks influencing in the profitability were analyzed. An important element of the macro-prudential analysis is the evidence of the internal and external factors and their relationship to the profitability of the banking sector and how this relationship is affected by institutional and structural characteristics. The results showed that almost all the factors were significant, whereas the sign of the relationship between the dependent and the independent variable was explained.

Ines and Sonia (2013) carried out a study related to explanatory factors of bank performance in Tunisia. Using the Generalized Method of Moments (GMM) estimator technique described by Blundell and Bond (1998), they identified factors explaining Tunisian bank performance. Retaining the main 10 commercial Tunisian banks during the 1998 to 2011 period, they examined whether, for banks operating in similar macroeconomic and financial development environments, one can make judgments concerning the success of their competitive strategies and other managerial procedure by using different profitability measures. The empirical results revealed a high degree of persistence of bank performance. By the other hand, the findings suggested that the bank capitalization, as well as the best managerial efficiency, have a positive and significant effect on the bank performance. Private owned banks seem to be more profitable than state owned ones. However Inflation seems to affect negatively bank's net interest margin.

Ayanda et al. (2013) examined profitability determinants in the banking sector of the Nigerian economy, First Bank of Nigeria Plc only as a case study. Results revealed that contrary to views of some authors, bank size and cost efficiency did not significantly determine bank profitability in Nigeria. However, credit risk and capital adequacy were found to be significant drivers which affected bank profitability both in the long run and short run respectively. Also, while Liquidity affected bank profitability in the short run, labour efficiency affected bank profitability in the long run. But as for the external or macroeconomic variables which determined bank profitability, it is suggested that only broad money supply growth rate was found to be a 
significant driver both in the long run and in the short run.

Another study on the determinants of profitability of listed commercial banks in developing countries specifically focusing on Malawi during the period 2009-2012 using internal-based and external based profitability measurements by Lipunga (2014), employed correlation and multivariate regression analysis. Return on Assets (ROA) and Earnings Yield (EY) are used as proxies of internal and external profitability respectively. The results of the regression analysis suggest that bank size, liquidity and management efficiency have a statistically significant impact on ROA however capital adequacy has insignificant effect. On the other hand results suggested that earnings yield is significantly influenced by bank size, capital adequacy and management efficiency, whereas liquidity is found to have insignificant influence on Earnings yield.

Francis (2013) using an unbalanced panel of 216 commercial banks drawn from 42 countries in SubSaharan Africa (SSA) for the period 1999 to 2006, by applying the cost efficiency model, suggested that the explanatory variables are growth in bank assets, growth in bank deposits, capital adequacy, operational efficiency (inefficiency), and liquidity ratio as well as the macroeconomic variables of growth in GDP and inflation. The findings clearly showed that both bankspecific as well as macroeconomic factors explain the variation in commercial bank profitability over the study period and findings demonstrated the importance of both bank level as well as macroeconomic factors in explaining commercial bank profitability in Sub- Saharan Africa.

Vincent and Gemechu (2013) analyzed determinants of financial performance of commercial Banks in Kenya. The authors used linear multiple regression model and Generalized Least Square on panel data to estimate the parameters. The findings showed that bank specific factors significantly affect the performance of commercial banks in Kenya, except for liquidity variable. Onuonga (2014) analysed profitability of Kenya's top six commercial banks. The study aimed at investigating the impact of the internal determinants of profitability of Kenya's top six commercial banks over the period 2008-2013, The study used generalized least squares method to estimate the impact of bank assets, capital, loans, deposits and assets quality on banks profitability. The study used return on assets (ROA) as a measure of profitability. The findings revealed that bank size, capital strength, ownership, operations expenses, diversification do significantly influence profitability of the top six commercial banks in Kenya.

Kiganda (2014) suggested that macroeconomic factors (real GDP, inflation and exchange rate) have insignificant effect on bank profitability in Kenya with Equity bank in focus at 5\% level of significance and concluded that macroeconomic factors do not affect bank profitability in Kenya, implying that internal factors which relate to bank management significantly determine bank profitability in Kenya. From the above literature, this paper found a gap, whereby the reviewed studies did not analyse specifically the effect of external economic factors on to profitability of commercial banks using panel data.

\section{RESEARCH METHODOLOGY}

This section presents and discusses the research methodology used in this paper. Besides this, the chapter presents the sources of data, instruments of data collection, data analysis and presentation techniques which were used.

\section{TYPES OF DATA USED}

The researcher used secondary data as practical means of obtaining information related to the research topic. The data were obtained from 12 commercial banks in Rwanda. In collecting secondary data, annual reports were used. Researcher used financial reports of 2001-2017 from each commercial bank, the total observations $(\mathrm{N})$ were $12 * 17=204$. Therefore the type of data used in this study was panel data. A panel data set contains several observations on the variables for the same unit taken at different points in time. After reviewing all annual reports, the information was arranged into a meaningful and organized form in Microsoft excel. After that, the data into Microsoft excel were imported to R programming software to be analyzed. In dealing with reliability, the researcher wants to ensure the degree of consistency and stability of the instrument; hence the research examined several times by checking for reliability in relevance, clarity and ambiguity of items in the instrument. Cronbach's Alpha coefficient was tested used to measure internal consistency of the research tool, for each variable the value of Cronbach's Alpha coefficient was greater than $0.7(70 \%)$. R software was used in this paper. $\mathrm{R}$ is a programming language for statistical computing and graphics. The dependent 
variable under study is Return on Average Equity (R), while the explanatory variables are Real GDP Growth Rate (G), Inflation Rate (I), Currency Depreciation against USD (C) and Private Sector Credit Growth (P) Descriptive statistics and variables under study are presented into table 1.

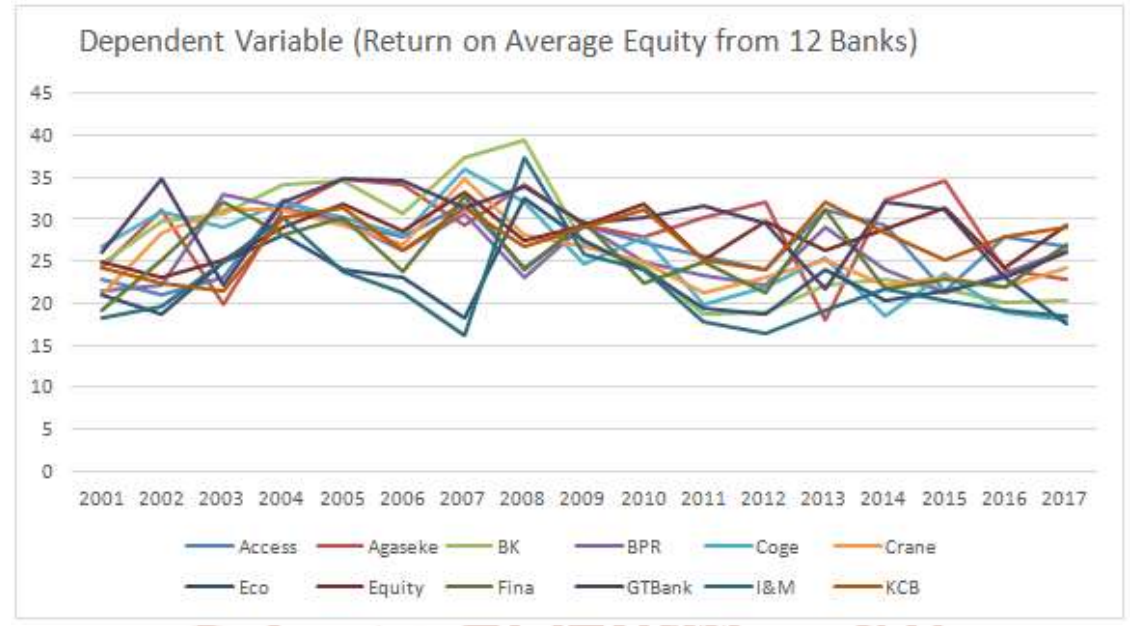

Figure 1: Return on Average Equity from 12 Banks

Figure 2 presents the data related to the dependent variable which is Return on Average Equity (R). The paper used the data from 12 commercial banks under time scope of 17 years (2001-2017). The names of selected commercial banks are access bank, Agaseke bank, bank of Kigali, Banque Populaire du Rwanda, cogebank, cranebank, econank, equity bank, finabank, GT bank, I\&M bank and KCB bank Rwanda. The Figure 2 indicates that there is a big difference among the profitability of commercial banks in Rwanda as indicated by return on average equity in this study. According to Pooran (2014), the Return on Average Equity (R) is a ratio relating net profit to shareholders' equity. The equity refers to share capital reserves and surplus of the bank. The Return on Average equity is (Profit after tax/ (Total equity + Total equity at the end of previous year)/2)*100. Return on equity indicates bank profitability by showing how much profit a bank generates with the money invested. Therefore, the higher ratio indicates the higher profitability of the banks, but from Figure 2 there is no consistent increment or decrement of return on average equity.

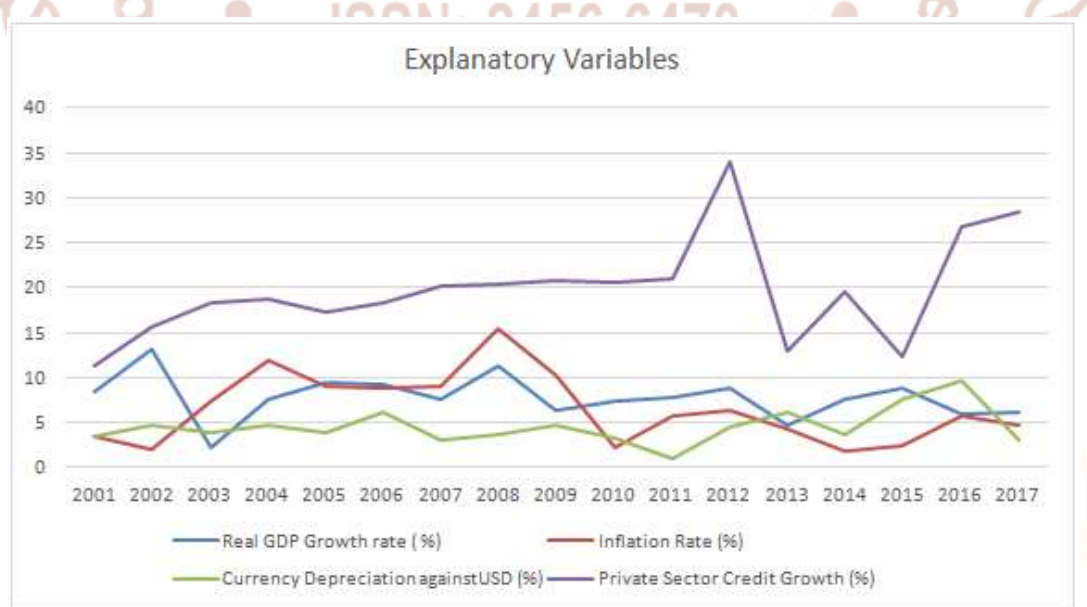

Figure 2: Explanatory Variables

Figure 3 presents the explanatory variables used in this research paper. There are may be many determinants that should affect the return on average equity in banking industry, like both internal and external factors. This study analyzed real GDP growth rate, inflation rate, currency depreciation against USD and private sector credit growth, because most of the study carried out before did not focus specifically on these determinants. From Figure 3, in 2008 the inflation rate was very high, but real GDP growth rate and return on average equity of best performer commercial bank in Rwanda (Bank of Kigali) were not bad, whereby most of other Rwandan commercial banks were affected by world economic crises . 
International Journal of Trend in Scientific Research and Development (IJTSRD) ISSN: 2456-6470

Table 1: Descriptive statistics

\begin{tabular}{|c|c|c|c|c|c|}
\hline Variables /Descriptive Statistics & N & Minimum & Maximum & Mean & Standard deviation \\
\hline Return on Average Equity (R) & 204 & 16.2 & 39.4 & 26.38 & 26.18 \\
\hline Real GDP Growth rate (G) & 204 & 2.2 & 13.2 & 7.782 & 7.6 \\
\hline Inflation Rate (I) & 204 & 1.8 & 15.4 & 6.518 & 5.7 \\
\hline Currency Depreciation against USD (C) & 204 & 0.9 & 9.7 & 4.544 & 3.9 \\
\hline Private Sector Credit Growth (P) & 204 & 11.4 & 33.9 & 19.78 & 19.6 \\
\hline
\end{tabular}

Source: Researcher, 2018

Table 1 presents descriptive statistics related to the variables under study, such as return on average equity, real GDP growth rate, inflation rate, currency depreciation against USD and private sector credit growth. The descriptive statistical analysis were done using $\mathrm{R}$ software. The number of observations $(\mathrm{N}=204)$, in this paper mean and median helped to review the measure of central tendency while measures of variability included the standard deviation, the minimum and maximum.

\section{STATISTICAL MODEL AND TESTS}

This subsection describe the statistical model and tests used in this paper. Panel data regression model, $Y=$ $X \beta+\mu$ and $\mu_{i t}=a_{i}+n_{i t}$ (1). Where $\mathrm{Y}$ is the (MT*1) matrix of dependent variable, $\mathrm{X}$ is the (MT*K) matrix of independents variables $\beta$ is the $\left(\mathrm{K}^{*} 1\right)$ matrix of coefficient and $\mu$ is the $\left(\mathrm{MT}^{*} 1\right)$ matrix of random error term, $\mathrm{N}$ is the number of cross sectional, $\mathrm{T}$ is the number of time period and $\mathrm{K}$ is the number of explanatory variables under study. Assume that $n_{i t}$ is uncorrelated (not correlated) with $\mathrm{X}_{\mathrm{it}}$, this implies that $\mathrm{E}$ $\left(\mathrm{X}_{\mathrm{it}}, \mathrm{n}_{\mathrm{it}}\right)=0$, where $\mathrm{a}_{\mathrm{i}}$ is called individual specific effect, varies across individuals but it constant across time. If $\mathrm{a}_{\mathrm{i}}$ is uncorrelated with explanatory variable $\left(X_{\mathrm{it}}\right)$, this implies that $\mathrm{E}\left(\mathrm{a}_{\mathrm{i}}, \mathrm{X}_{\mathrm{it}},\right)=0$, then we have Random Effect Model (REM) and when $a_{i}$ is correlated with $X_{i t}$, this implies that $E\left(a_{i}, X_{i t}, \neq 0\right.$, then we have Fixed Effect Model (FEM).

Before the application of the estimation model, we first have to test the true nature of the panel data. The true model has been chosen in the following way. Basically, for testing the true nature of the data we have to do the following test: Lagrange multiplier (LM) test; Lagrange multiplier test whether the model is Classical Linear Regression Model (CLRM) or Random Effect Model (REM). Restricted F-test; Restricted F-test whether the model is Classical Linear Regression Model (CLRM) or Fixed Effect Model (FEM), while Hausman test indicates whether the model is Random Effect Model (REM) or Fixed Effect Model (FEM).

According to Jana (2017) we choose CLRM and apply ordinary least square (OLS) method when both Restricted F-test and Lagrange multiplier (LM) test are insignificant. We choose REM and apply Generalized Least Square (GLS) method when Restricted F-test is insignificant and LM test is significant. In case both Restricted F-test and LM are significant, then we shall apply REM if Hausman test is insignificant. We choose FEM when LM-test is insignificant but restricted F-test is significant. In case both Restricted F-test and LM test are significant, then we shall apply FEM if Hausman test is significant. Moreover, the above general review of research methodology helped the researcher to examine the effect of external economic factors on Return On Average Equity $(\mathrm{R})$ in the selected Rwandan commercial banks using panel data models. Where the empirical model generated from equation (1) is represented by equation (2) as indicated below:

$R_{i t}=\beta_{0}+\beta_{1} G_{i t}+\beta_{2} I_{i t}+\beta_{3} C_{i t}+\beta_{4} P_{i t}+\mu_{i t}$

Where,

i : Specific bank

t: The examined time period

$R_{i t}$ : Return on Average equity of bank i at time $\mathrm{t}$

$G_{i t}$ : Real GDP Growth Rate of bank i at time $\mathrm{t}$

$I_{i t}:$ Inflation Rate of bank $\mathrm{i}$ at time $\mathrm{t}$

$C_{i t}$ : Currency Depreciation against USD of bank $\mathrm{i}$ at time $\mathrm{t}$ 
$P_{i t}:$ Private Sector Credit Growth of bank i at time $\mathrm{t}$

$\beta 1, \beta 2, \beta 3$ and $\beta 4$ are coefficients of the independents variables

$\mu_{i t}:$ Random error term

$\beta_{0}$ : Intercept / Constant

\section{RESULTS AND DISCUSSION}

This section focuses on the analysis of the panel data and statistical tests used in this paper. The data were obtained from 12 commercial banks in Rwanda. Researcher used financial reports of 2001-2017 from each commercial bank, the total observations $(\mathrm{N})$ were $12 * 17=204$. Lagrange multiplier test whether the model is Classical Linear Regression Model (CLRM) or Random Effect Model (REM). Restricted F-test indicates whether the model is Classical Linear Regression Model (CLRM) or Fixed Effect Model (FEM), while Hausman test indicates whether the model is Random Effect Model (REM) or Fixed Effect Model (FEM).

Table 2: Classical Linear Regression Model

\begin{tabular}{|c|c|c|c|c|c|c|}
\hline Explanatory variables & Estimate & Std. Error & t-value & $\operatorname{Pr}(>|\mathrm{t}|)$ & R-Squared & Adj. R-Squared \\
\hline Intercept & 25.92738 & 1.873262 & 13.8408 & $<2.2 \mathrm{e}-16 * * *$ & & \\
\hline G & 0.089861 & 0.131021 & 0.6859 & 0.493602 & & \\
\hline I & 0.551624 & 0.084387 & 6.5368 & $5.166 \mathrm{e}-10 * * *$ & 0.20053 & 0.18446 \\
\hline C & -0.17698 & 0.162092 & -1.0918 & 0.27623 & & \\
\hline P & -0.15359 & 0.056896 & -2.6994 & $0.007544 * *$ & & \\
\hline
\end{tabular}

F-statistic: 12.479 on 4 and $199 \mathrm{DF}, \mathrm{p}$-value: $4.4655 \mathrm{e}-09$

$\mathrm{R} \sim \mathrm{G}+\mathrm{I}+\mathrm{C}+\mathrm{P}$

\section{Source: Researcher}

Table 2 presents the results related to classical linear regression model from $\mathrm{R}$ software, where the researcher analyzed the effect of real GDP growth rate $(\mathrm{G})$, inflation rate (I), currency depreciation against USD (C) and private sector credit growth $(\mathrm{P})$ on return on average equity $(\mathrm{R})$. Classical linear regression model is a model statistical-tool used in predicting future values of a dependent variable on the basis of the behavior of a set of explanatory factors. According to Jana (2017) we choose CLRM and apply ordinary least square (OLS) method when both Restricted F-test and Lagrange multiplier(LM) test are insignificant.

Table 3: Fixed Effects Estimation

\begin{tabular}{|c|c|c|c|c|c|c|}
\hline Explanatory variables & Estimate & Std. Error & t-value & $\operatorname{Pr}(>|\mathrm{t}|)$ & R-Squared & Adj. R-Squared \\
\hline G & 0.089724 & 0.117619 & 0.7628 & 0.446517 & & \\
\hline I & 0.551532 & 0.075755 & 7.2805 & $8.826 \mathrm{e}-12 * * *$ & 0.24793 & 0.18792 \\
\hline C & -0.179212 & 0.145559 & -1.2312 & 0.219785 & & \\
\hline P & -0.153617 & 0.051076 & -3.0076 & $0.002993 * *$ & & \\
\hline
\end{tabular}

F-statistic: 15.4941 on 4 and $188 \mathrm{DF}$, p-value: $5.6762 \mathrm{e}-11$

$\mathrm{R} \sim \mathrm{G}+\mathrm{I}+\mathrm{C}+\mathrm{P}$, Where $\mathrm{R}$ is dependent variable

\section{Source: Researcher}

Table 3 presents results related to the fixed effects estimation from R software. The analysis was also based on the effect of real GDP growth rate $(\mathrm{G})$, inflation rate (I ), currency depreciation against USD (C) and private sector credit growth $(\mathrm{P})$ on return on average equity $(\mathrm{R})$ in Rwandan commercial banks. We choose fixed effects model when Lagrange Multiplier-test is insignificant but restricted F-test is significant. In case both Restricted F-test and LM test are significant, then we shall apply FEM if Hausman test is significant.

Table 4: Random Effects Estimation Before Removing Insignificant Variables

\begin{tabular}{|c|c|c|c|c|c|c|}
\hline Explanatory Variables & Estimate & Std. Error & t-value & $\operatorname{Pr}(>|\mathrm{t}|)$ & R-Squared & Adj. R-Squared \\
\hline Intercept & 25.9377 & 1.78605 & 14.5224 & $<2.2 \mathrm{e}-16 * * *$ & & \\
\hline G & 0.089747 & 0.117341 & 0.7648 & 0.445272 & & \\
\hline I & 0.551548 & 0.075576 & 7.2979 & $6.825 \mathrm{e}-12 * * *$ & 0.23832 & 0.22301 \\
\hline C & -0.17883 & 0.145207 & -1.2316 & 0.21957 & & \\
\hline P & -0.15361 & 0.050956 & -3.0146 & $0.002908 * *$ & & \\
\hline
\end{tabular}


$\mathrm{R} \sim \mathrm{G}+\mathrm{I}+\mathrm{C}+\mathrm{P}$, Where $\mathrm{R}$ is dependent variable, F-statistic: 15.5659 on 4 and $199 \mathrm{DF}$, p-value: 4.2607e-11, theta: 0.5868

Table 5: Random Effects Estimation After Removing Insignificant Variables

\begin{tabular}{|c|c|c|c|c|c|c|}
\hline Explanatory Variables & Estimate & Std. Error & t-value & $\operatorname{Pr}(>|\mathrm{t}|)$ & R-Squared & Adj. R-Squared \\
\hline Intercept & 25.80424 & 1.226347 & 21.042 & $2.2 \mathrm{e}-16 * * *$ & & \\
\hline I & 0.563706 & 0.075362 & 7.48 & $2.264 \mathrm{e}-12 * * *$ & 0.22883 & 0.22116 \\
\hline P & -0.15664 & 0.050665 & -3.092 & $0.002272 * *$ & & \\
\hline
\end{tabular}

$\mathrm{R} \sim \mathrm{I}+\mathrm{P}$, Where $\mathrm{R}$ is dependent variable, F-statistic: 29.8215 on 2 and $201 \mathrm{DF}$, p-value: 4.5559e-12, theta: 0.5675

\section{Source: Researcher}

Table 4 and Table 5 presents results from $\mathrm{R}$ software related to random effects estimation, respectively before and after removing insignificant variables. The explanatory variables before removing insignificant variables are real GDP growth rate $(\mathrm{G})$, inflation rate $(\mathrm{I})$, currency depreciation against USD (C) and private sector credit growth $(P)$, respectively after removing insignificant variables $(G$ and $C$ ), certainly, the remained explanatory variables are I and $\mathrm{P}$, while dependent variable is still return on average equity ( $\mathrm{R}$ ). We choose REM and apply Generalized Least Square (GLS) method, when Restricted F-test is insignificant and LM test is significant. In case both Restricted F-test and LM are significant, then we shall apply REM if Hausman test is insignificant.

Table 6: Test the true nature of data

\begin{tabular}{|c|c|c|c|c|}
\hline Tests & Purpose & P-value & Significant & Decision \\
\hline LM test (plmtest) & REM versus CLRM & $5.85 E-15$ & Yes & \\
\hline Restricted F-test (pFtest) & FEM versus CLRM & $2.25 E-07$ & Yes & \\
\hline Hausman test (phtest) & REM versus FEM & $\sim 1$ & No & Take REM \\
\hline
\end{tabular}

\section{Source: Researcher}

Before the application of the estimation model, we first have to test the true nature of the panel data. The true model has been chosen by using Lagrange Multiplier test for Random Effects Model versus Classical Linear Regression Model (plmtest), Restricted F-test used for Fixed Effects Model versus Classical Linear Regression Model (pFtest), and Hausman test for Fixed Effects Model versus Random Effects Model (phtest). For Lagrange Multiplier test, we found that statistical test, normal $=7.7193$ and Pvalue $=5.851 \mathrm{e}-15$ less than 0.05 , the P-value is very small. This implies that LM-test is significant. $F$ test for individual effects ( $\mathrm{pFtest}$ ) indicated that $\mathrm{F}=$ $5.3577, \mathrm{df} 1=11, \mathrm{df} 2=188, \mathrm{p}$-value $=2.254 \mathrm{e}-07$ less than 0.05 , this implies that restricted F-test is significant. The Hausman test was used for fixed effects model versus random effects model, where chisq $=0.0014278, \mathrm{df}=4, \mathrm{p}$-value $\sim 1$, in this case, Hausman test is insignificant. In this case both Restricted F-test and Lagrange Multiplier test are significant and Hausman test is insignificant, then we apply Random Effect Model. Then, we have to follow results in Table 5.

\section{SUMMARY AND CONCLUSION}

The summary and conclusion of this study was done based on the research hypothesis, results in Table 6 which indicates the true nature of data and results in Table 4 and Table 5 related to the Random Effects Model. The number of research hypothesis were four as follow:

(i) there is no significant effect of inflation rate on return on average equity in Rwandan selected commercial banks, (ii) there is no significant effect of GDP Growth rate on return on average equity in Rwandan selected commercial banks, (iii) there is no significant effect of currency depreciation on return on average equity in Rwandan selected commercial banks, (iv) there is no significant effect of private sector credit growth on return on average equity in Rwandan selected commercial banks.

According to the first research hypothesis related to effect of inflation rate on return on average equity in Rwandan selected commercial banks, the null hypothesis was rejected. The results indicate that if inflation rate changes at $1 \%$, return on average equity changes positively at 0.563706 . Therefore, the 
findings indicated that there is a significant positive effect of inflation rate on return on average equity in Rwandan selected commercial banks. This significant positive effect was confirmed by (Yong and Christos, 2012), where they indicated that the a positive relationship between bank profitability and inflation can be caused by cost efficiency, banking sector development, stock market development and competitiviness in the banking sector.

In relation to the second research hypothesis related to effect of GDP Growth rate on return on average equity in Rwandan selected commercial banks, the null hypothesis was failed to be rejected. Therefore, there is no significant effect of GDP Growth rate on return on average equity in Rwandan selected commercial banks.

In relation to the third research hypothesis related to the effect of currency depreciation on return on average equity in Rwandan selected commercial banks, the null hypothesis was failed to be rejected. Therefore, the findings indicated that there is no significant effect of currency depreciation on return on average equity in Rwandan selected commercial banks.

Lastly, in regards to the fourth research hypothesis related to effect of private sector credit growth on return on average equity in Rwandan selected commercial banks, the null hypothesis was rejected, the results indicate that if private sector credit growth changes at $1 \%$, return on average equity changes at 0.156643 . Therefore, the findings indicated that there is a significant negative effect of private sector credit growth on return on average equity in Rwandan selected commercial banks. This negative effect was also confirmed by (Perez1, 2017), he indicated that there is negative relationship between private sector credit growth rate and domestic banks' equity if managers of commercial banks do not pay attention on non-performing loans and credit risk mitigation. From Table 5, the results also indicated that the value of R-Squared equals to $0.22883=22.883 \%$. Finally, from the value of R-Squared equals to $0.22883=$ $22.883 \%$, this study concluded that, inflation rate and private sector credit growth can only affect the return on average equity in commercial bank on the rate of $22.883 \%$. This implies that there may be other factors, like internal factors that should affect the return on average equity in commercial banks. The study ended by recommending researchers to carry out more studies on both internal and external factors, because external factors may have negative or positive effect due to other factors as indicated by this paper and other previous researchers.

\section{RECOMMENDATIONS AND SUGGESTIONS}

Banks, investors and other financial market players can therefore employ panel dada analysis model in predicting equity uptake given several microeconomic factors including foreign remittances. Given the effects of foreign remittances on equity, commercial banks should also use this study to enhance tapping foreign remittances from informal channels so as to increase their revenue through processing fees and also improve their short term liquidity. Researchers should expand this study by incorporating other factors not captured in this study and compare the results. A separate study should also be carried out to determine to what extent do both external and internal economic factors contribute to the Financial inclusion in Rwanda.

\section{REFERENCES}

[1] Adeyemi, A. Adekunle, A. \& Taiwo,K. (2013). AN EMPIRICAL INVESTIGATION OF THE FINANCIAL REPORTING PRACTICES AND BANKS' STABILITY IN NIGERIA. Kuwait Chapter of Arabian Journal of Business and Management Review, Vol.2(5), PP.157 - 180.

[2] Allison, P. D. (2001). Missing data (Sage University Paper Series on Quantitative Applications in the Social Sciences series no. 07-136). Thousand Oaks, CA: Sage.

[3] Altunbas, Y., Evans, L., \& Molyneux, P. (2001). Bank Ownership and Efficiency. Journal of Money, Credit and Banking, 33(4), 926-954.

[4] Athanasoglou, P. P., Sophocles, N. B., \& Delis, M. D. (2008). Bank-specific, industry-specific and macroeconomic determinants of bank profitability. International Financial Markets, Institutions and Money, 18(2), 121-136.

[5] Ayadi, R., Llewellyn, D. T., Schmidt, R. H., Arbak, E., \& De Groen, W. P. (2010). Investigating Diversity in the Banking Sector in Europe: Key Developments, Performance and Role of Cooperative Banks. Brussels: Centre for European Policy Studies.

[6] Ayanda, A. M., Christopher, E. I., \& Mudashiru, M. A. (2013). Determinants of banks' profitability in developing economy: evidence 
International Journal of Trend in Scientific Research and Development (IJTSRD) ISSN: 2456-6470

from Nigerian banking industry. Interdisciplinary Journal of contemporary research in business, 4(2), 155-181.

[7] Bank of KIgali [BK]. (2014). Bank of KIgali [BK] annual report 2014. Kigali / Rwnda: Bank of KIgali [BK].

[8] Banque Populaire du Rwanda. (2014). Banque Populaire du Rwanda organization (employees) structure. Kigali - Rwanda: Banque Populaire du Rwanda.

[9] Barako, D. G. (2007). Determinants of voluntary disclosures in Kenyan companies annual reports. African Journal of Business Management, Vol.1(5), pp. 113-128.

[10] Berger, A. N. (1995). The Relationship between Capital and Earnings in Banking. Journal of Money, Credit and Banking, 27(2), 432-456.

[11] Bessis, J. (2010). Risk Management in Banking (3 ed.). London: Wiley.

[12] Brunilda, D. \& Elvana, M. (2015). FACTORS INFLUENCING THE BANK PROFITABILITY. Asian Economic and Financial Review, 5(3), 483-494.

[13] Campbell, A. (2007). Bank insolvency and the problem of nonperforming loans. Journal of banking regurations, Vol.9(1), pp. 25 - 45.

[14] Christos, K. S. \& Geoffrey, E. W. (2014). The Determinants Of European Bank Profitability. International Business \& Economics Research Journal, 3(6), 57 - 68.

[15] Dang, U. (2011). The CAMEL Rating System in Banking Supervision: a Case Study of Arcada. Hochschule Karlsruhe: University of Applied Sciences.

[16] Demirgüç-Kunt, A., \& Huizinga, H. (1999). Determinants of Commercial Bank Interest Margins and Profitability: Some International Evidence. The World Bank Economic Review, 13(2), 379-408.

[17] Diamond, D. (2002). Financial Intermediation and delegated monitoring. Review of Economic Studies, 51(3), 393-414.

[18] Diamond, D.W., \& Raghuram, A. (2000). A Theory of Bank Capital. The Journal of Finance, 52(6), 12 - 23.
[19] Dwight, L. (2004). The Role of Non-Performing Loans in china. Beijing: A Public Finance Approach.

[20] Fisseha, F. L. (2015). META ANALYSIS ON THE DETERMINANTS OF COMMERCIAL BANK'S PROFITABILITY: (A CONCEPTUAL FRAME WORK AND MODELLING). European Scientific Journal, 11(19), 323 - 351.

[21] Francis, M. (2013). Determinants of Commercial Bank Profitability in Sub-Saharan Africa. International Journal of Economics and Finance, 5(9), 11 - 24.

[22] Gale, A. (2004). Competition and financial stability. Journal of Money Credit and Banking, Vol.36, pp. 453-481.

[23] Gul, S., Faiza, I., \& Khalid, Z. (2011). Factors Affecting Bank Profitability in Pakistan. The Romanian Economic Journal, 2(3), 6-9.

[24] Hippolyte, F. (2005). Nonperforming Loans In Sub-Saharan Africa: Causal analysis and macro economic implications. London: World Bank.

[25] Ines, G. B., \& Sonia, M. M. (2013). Explanatory Factors of Bank Performance Evidence from Tunisia. International Journal of Economics, Finance and Management, 2(1), 143 - 152.

[26] James, O. A. \& Solomon,O . (2012). Compliance with Regulatory Financial Reporting and Corporate Governance Practices in Selected Primary Mortgage Institutions in Nigeria. International Journal of Business and Social Science, Vol.3(15), PP.246 - 254.

[27] Jana, S. K. (2017). Determinants of Profitability of Banks in India: A Panel Data Analysis. Scholars Journal of Economics, Business and Management, 4(7), 436-445.

[28] Kariuki, G. \& Jagongo, A. (2013). Institutional Investors' Perceptions on Quality of Financial Reporting in Kenya. International Journal of Humanities and Social Science, Vol.3(21), PP.144 - 156.

[29] Khrawish, H. (2011). Determinants of Commercial Banks Performance: Evidence from Jordan. International Research Journal of Finance and Economics, 5(5), 19-45.

[30] Kiganda, K. (2014). Effect of Macroeconomic Factors on Commercial Banks Profitability in 
International Journal of Trend in Scientific Research and Development (IJTSRD) ISSN: 2456-6470

Kenya: Case of Equity Bank Limited. Journal of Economics and Sustainable Development, 5(2), $1-12$.

[31] Levine, R., \& Loayza, N. (2000). Financial intermediation and growth: Causality and causes. Journal of Monetary Economics, 4(46), $31-77$.

[32] Lipunga, A. (2014). Determinants of Profitability of Listed Commercial Banks in Developing Countries: Evidence from Malawi. Research Journal of Finance and Accounting, $5(6), 12$ - 25.

[33] Manuel, D. (2014). A History of Bank Failures in the United States. New York : DaveEmma.

[34] Ministry of Finance and Economic Planning [MINECOFINE]. (2015). RWANDA FINANCIAL SECTOR STRATEGY. Kigali: Government of Rwanda.

[35] Molyneux, P., \& Thornton, J. (1992). Determinants of European bank profitability: A note. Journal of Banking and Finance, 16(6), 1173-1178.

[36] Murthy, Y., \& Sree, R. (2003). A Study on Financial Ratios of major Commercial Banks. Sultanate of Oman: College of Banking \& Financial Studies.

[37] National Bank of Rwanda [BNR]. (2015). Evaluating loans portfolio and the financial position of financial institutions. Kigali Rwanda: National Bank of Rwanda [BNR].

[38] Ong, T. S. \& Teh, B. H. (2013). Factors affecting the profitability of Malaysian commercial banks. African Journal of Business Management, 7(8), 649-660.

[39] Ongore, V. O. (2013). Determinants of Financial Performance of Commercial Banks in Kenya. International Journal of Economics and Financial Issues, 3(1), 237-252.

[40] Onuonga, S. (2014). The Analysis of Profitability of Kenya's Top Six Commercial Banks: Internal Factor Analysis. American International Journal of Social Science, Vol.3(5), 94 - 103.

[41] Onuonga, S. M. (2014). The Analysis of Profitability of Kenya`s Top Six Commercial Banks: Internal Factor Analysis. American
International Journal of Social Science, Vol.3(5), 94 - 103.

[42] Paul, K. (2001). Information asymmetry,Corporate disclosur and Capital markets. Journal of Accounting and Economics, Vol.31, pp.405-440.

[43] Perez1, P. (2017). An Analysis of Private Sector Credit Growth in Belize: A VECM Approach. 49th annual monetary studies conferences (pp. 1 - 29). Belize / Radisson Fort George: Central Bank of Belize.

[44] Pooran, L. (2014). Factors affecting U.S. Banking Performance: Evidence From the 20072013 Financial Crisis. International Journal of Economics, Finance and Management, 3(6), 282 $-295$.

[45] Praveen, P. (1990). Information asymmetries: source of competitive advanatage for diversified service firms. Strategic Management journal, PP.513-519.

[46] Sangmi, M., Tabassum, N. (2010). Analyzing Financial Performance of Commercial Banks in India: Application of CAMEL Model. Pakistan Journal Commercial Social Sciences, 1(1), 110.

[47] Santomero \& Anthony M.,. (1984). Modelling the Banking Firm: A Survey. Journal of Money, Credit and Banking, vol.16(4), pp.576-602.

[48] Short, B. K. (1979). The relation between commercial bank profit rates and banking concentration in Canada, Western Europe, and Japan. Journal of Banking and Finance, 3(3), 209-219.

[49] Waqas, T., Muhammad, U., Haseeb, Z., Inam, A., \& Imran, A. (2014). Determinants of Commercial Banks Profitability: Empirical Evidence from Pakistan. International Journal of Accounting and Financial Reporting, 4(2), 1 22.

[50] Varian, V. (2000). Microeconomia: Rio de Janeiro: W. W. Norton \& Company.

[51] Waseem, M.,Saleh, T. \& Fares, J. (2011). The Effect of Corporate Governance on the Performance of Jordanian Industrial Companies: An empirical study on Amman Stock Exchange. International Journal of Humanities and Social Science, Vol.1(4), PP.55 - 69. 
International Journal of Trend in Scientific Research and Development (IJTSRD) ISSN: 2456-6470

[52] Wen, W. (2010). Ownership Structure and Banking Performance: New Evidence in China. Barcelona: Universitat Autònoma de Barcelona Departament D'economia de L'empresa.

[53] Vincent, B. \& David, N. (2012). The effects of credit policy on bank performance: Evidence from selected Rwandan Commercial banks. Rwanda Journal, 26(2), 116 - 119.

[54] Vincent, O. \& Gemechu, B. (2013). Determinants of Financial Performance of Commercial Banks in Kenya. International Journal of Economics and Financial Issues, 3(1), 237-252.

[55] Yong, A. and Christos, F. (2012). Bank profitability and inflation: The case of China. Journal of Economic Studies, 39(6), 675-696.

[56] Yount, R. (2006). Correlation Coefficients : the Meaning of Correlation. Rick Yount. 